\title{
ANÁLISE MOLECULAR DE SEGMENTO DO RNA2 DE Comovirus ISOLADOS DE SOJA NO ESTADO DO PARANÁ
}

\author{
ELIEZER R. SOUTO ${ }^{1}$, ÁLVARO M. R. ALMEIDA², ANÉSIO BIANCHINI ${ }^{3}$, \\ FÁBIO SARTORI ${ }^{4} \&$ ÉBERSON S. CALVO
}

\begin{abstract}
${ }^{1}$ Depto de Agronomia, Universidade Estadual de Maringá, Av. Colombo 5790, CEP 87020-900, Maringá, PR,

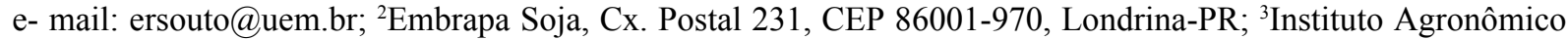
do Paraná, Cx. Postal 481, CEP 86001-970, Londrina, PR; ${ }^{4,5}$ Milenia Biotecnologia \& Genética Ltda., Rua Pedro Antônio de Souza 405, CEP 86031-610, Londrina, PR
\end{abstract}

(Aceito para publicação em 11/06/2002)

Autor para correspondência: Eliezer R. Souto

SOUTO, E.R., ALMEIDA, A.M.R., BIANCHINI, A., SARTORI, F. \& CALVO, E.S. Análise molecular de segmento do RNA2 de Comovirus isolados de soja no Estado do Paraná. Fitopatologia Brasileira 27:525-527. 2002.

\section{RESUMO}

Nas áreas produtoras de feijão (Phaseolus vulgaris) do Estado do Paraná observa-se anualmente a ocorrência do vírus do mosaico em desenho do feijoeiro (Bean rugose mosaic virus, BRMV), principalmente em infecções mistas com o vírus do mosaico dourado do feijoeiro (Bean golden mosaic virus, BGMV), acarretando maior severidade de sintomas e causando perdas na produção. Recentemente constatou-se a presença do vírus do mosaico severo do caupi (Cowpea severe mosaic virus, CPSMV) associado a sintomas de queima do broto em plantações de soja (Glycine max) na região de Londrina, sendo este um fato novo no Estado. Neste trabalho, parte do RNA2 de dois comovirus isolados de soja no Paraná foram clonados e sequenciados, sendo 600 pares de bases (pb) do BRMV-PR e $594 \mathrm{pb}$ do CPSMV-PR. Posteriormente, as seqüências correspondentes de aminoácidos foram comparadas com seis seqüências de vírus do gênero Comovirus depositadas no GenBank. Com base nestes dados observou-se que o segmento do RNA2 do isolado CPSMV-PR apresentou homologia de $85 \%$ com parte de uma seqüência já conhecida do RNA2 do CPSMV, enquanto que o segmento do RNA2 do isolado BRMV-PR apresentou homologia de $39 \%$ com o CPSMV, e de $44 \%$ com o Bean pod mottle virus (BPMV). Este trabalho apresenta pela primeira vez dados de sequenciamento parcial do BRMV, o que poderá contribuir para sua completa caracterização molecular e para o estabelecimento de estratégias para obtenção de plantas resistentes ao vírus.

Palavras-chave adicionais: BRMV, CPSMV, dados de seqüenciamento.

\section{ABSTRACT \\ Molecular analysis of RNA2 segment of comoviruses isolated from soybean in the State of Paraná}

In bean (Phaseolus vulgaris) producing areas of Paraná State, Bean rugose mosaic virus (BRMV) has been found in mixed infections with Bean golden mosaic virus (BGMV) increasing the severity of symptoms and crop losses. The association of Cowpea severe mosaic virus (CPSMV) with bud blight symptoms in soybean (Glycine max) plants was recently observed in Paraná for the first time. In this work RT-PCR products of $600 \mathrm{bp}$ of BRMV-PR RNA2 and $594 \mathrm{bp}$ of CPSMV-PR RNA2 were cloned and sequenced. The amino acid sequences coded by the RNA2 segment from these isolates were compared with sequences of the same RNA2 genomic region of six comovirus species from the GenBank. The CPSMVPR showed $85 \%$ homology with the CPSMV RNA2 from the GenBank. Moreover, the BRMV-PR isolate showed 39 and $44 \%$ homology with CPSMV and Bean pod mottle virus (BPMV), respectively. This work shows, for the first time, partial sequencing data for BRMV. This data may be helpful for the complete molecular characterization of this virus and for establishing strategies to obtain virus resistant plants.
O genoma dos vírus do gênero Comovirus é composto de dois RNAs de fita simples, senso positivo, denominados RNA1 ou RNA-B ("bottom component") e RNA2 ou RNA-M ("middle component"), encapsulados separadamente em partículas icosaédricas de diâmetro aproximado de $28 \mathrm{~nm}$. No caso do vírus do mosaico do caupi (Cowpea mosaic virus, CPMV), membro tipo do gênero Comovirus, família Comoviridae, quantidades similares de dois polipeptídeos de pesos moleculares de 23.000 e 37.000 , proteínas S e L, constituem a capa protéica das partículas. Ambos os RNAs são necessários para a infecção sistêmica da planta hospedeira. O RNA1 codifica proteínas para a replicação, enquanto o RNA2 codifica proteínas para o movimento do vírus de célula a célula e à longa distância (proteínas MP), e as proteínas do capsídeo (Chen \& Bruening, 1992).

Dois vírus do gênero Comovirus foram identificados 
no Estado do Paraná infetando plantas de soja (Glycine max L.). O primeiro foi isolado de plantas de soja apresentando sintomas de queima do broto, identificado como o CPSMV, tendo sido determinadas as suas propriedades biológicas e físico-químicas (Bertacini et al., 1998). O segundo, obtido também a partir de plantas de soja, foi identificado através de testes sorológicos, transmissão por Diabrotica speciosa Germ., inoculação mecânica em hospedeiras diferenciadoras e microscopia eletrônica, como sendo um isolado do vírus do mosaico em desenho do feijoeiro (Bean rugose mosaic virus, BRMV) da família Comoviridae, gênero Comovirus (Martins et al., 1994).

No Brasil o CPSMV foi detectado em plantas de 23 espécies vegetais da família Leguminosae (Bertacini et al., 1998; Brioso et al., 1994), enquanto o BRMV foi detectado em soja (Cupertino et al., 1991) e feijoeiro (Phaseolus vulgaris L.) (Cupertino et al., 1982; Bianchini et al., 1985).

A presença do BRMV tem sido observada com freqüência em grande parte das regiões produtoras do Cerrado e do Estado do Paraná. Nas áreas produtoras do Paraná, temse observado a cada ano aumento da ocorrência do BRMV, principalmente em infecção mista com o vírus do mosaico dourado do feijoeiro (Bean golden mosaic virus, BGMV), pertencente à família Geminiviridae, gênero Begomovirus, e o vírus do mosaico-comum da soja (Soybean mosaic virus, SMV), família Potyviridae, gênero Potyvirus, ocasionando sintomas de encarquilhamento ou superbrotamento (Bianchini et al.,1985; Martins et al., 1994).

Considerando-se as características de seus insetos vetores, que são polífagos e ocorrem em todo o país e em todas as épocas do ano, vírus como o BRMV poderão se tornar problema sério em soja e feijoeiro, devido ao cultivo sucessivo, proximidade dessas culturas e severidade das infecções mistas.

Este trabalho procurou determinar parte da organização genômica do BRMV e CPSMV isolados de soja no Paraná, o que poderá contribuir para estudos de divergência genética dos isolados brasileiros de comovirus de leguminosas, e para a utilização de medidas de controle através de estratégias de resistência genética a vírus.

O isolado do CPSMV de soja utilizado neste estudo foi mantido por inoculação mecânica periódica em plantas de soja e o BRMV isolado de soja foi mantido em feijoeiro 'Rio Tibagi' também via inoculação mecânica.

RNAs totais foram extraídos de $100 \mathrm{mg}$ de tecido vegetal fresco, triturado em nitrogênio líquido, conforme o método de extração RNeasy ${ }^{\circledR}$ Plant Kit protocol (Qiagen $\left.{ }^{\circledR}\right)$. Foram utilizadas folhas de soja infetadas pelo CPSMV-PR e de feijoeiro infetadas pelo BRMV-PR.

Para a síntese da fita simples de cDNA, foram utilizados $10 \mu \mathrm{l}$ de RNAs totais obtidos de plantas infetadas. A seguir, foram adicionados $2 \mu \mathrm{l}$ da solução $(10 \mu \mathrm{g} / \mu \mathrm{l})$ do oligonucleotídeo 'antisenso' 5'-YTCRAAWCCVYTRTTKG GMCCACA-3' (Brioso et al., 1996). As amostras foram aquecidas a $80{ }^{\circ} \mathrm{C}$ por $3 \mathrm{~min}$, resfriadas no gelo, e a seguir foram adicionados os demais componentes da reação, $6 \mu$ l do tampão de transcrição reversa 10x (200 mM Tris-HCl, $\mathrm{pH} 8,4,500$
mM KCl), 2 il de $\mathrm{MgCl}_{2}(25 \mathrm{mM}), 1 \mu \mathrm{l}$ da mistura de dNTPs (10 mM de cada), $2 \mu$ de DTT $(0,1 \mathrm{M}), 2 \mu \mathrm{l}$ da enzima transcriptase reversa do M-MLV (Gibco BRL, $50 \mathrm{U} / \mu \mathrm{l}$ ) e 6 $\mu 1$ de água tratada com DEPC. As amostras foram colocadas para incubar a $37^{\circ} \mathrm{C}$ por $1 \mathrm{~h}$ e depois a $65^{\circ} \mathrm{C}$ por $10 \mathrm{~min}$.

Para a reação de PCR, foram utilizados o oligonucleotídeo 'antisenso' 5'-YTCRAAWCCVYTRTTKGGMCC ACA-3 e o oligonucleotídeo 'senso' 5-GCATGGTCCACWC AGGT-3' (Brioso et al., 1996). Os oligonucleotídeos utilizados correspondem às seqüências de aminoácidos conservados, AWSTQV, presente na subunidade L, e GPN*GFE $(*=\mathrm{N}$ ou $\mathrm{R})$, presente na subunidade $\mathrm{S}$ do capsídeo dos comovirus, codificadas pelo RNA2.

As soluções de PCR foram preparadas em volume total de $40 \mu \mathrm{l}$, contendo $1 \mu \mathrm{l}$ da mistura de dNTPs (10 mM cada), $2 \mu \mathrm{l}$ de cada oligonucleotídeo $(10 \mu \mathrm{M}), 0,5 \mu \mathrm{l}$ de Taq DNA Polimerase (Gibco-BRL, $5 \mathrm{U} / \mu \mathrm{l}), 5 \mu \mathrm{l}$ de tampão PCR 10x (200 mM Tris-HCl, pH 8,4, 0,5 M KCl) $3 \mu \mathrm{lde} \mathrm{MgCl}_{2}(25$ $\mathrm{mM}), 4 \mu \mathrm{l}$ do produto da síntese de cDNA, e 22,5 $\mu \mathrm{l}$ de água destilada e deionizada. Trinta e cinco ciclos de reação foram conduzidos com desnaturação a $94{ }^{\circ} \mathrm{C}$ por $30 \mathrm{~s}$, anelamento a $40{ }^{\circ} \mathrm{C}(\operatorname{ciclos} 1-5)$ e $50{ }^{\circ} \mathrm{C}(\operatorname{ciclos} 6-35)$ por 1 min, e extensão a $72{ }^{\circ} \mathrm{C}$ por $2 \mathrm{~min}$. Ao final, as amostras foram incubadas por $10 \mathrm{~min}$, a $72{ }^{\circ} \mathrm{C}$.

Alíquotas de $10 \mu \mathrm{l}$ dos produtos de PCR foram visualizados através de eletroforese em gel de agarose a 1,2\% corados com brometo de etídio $(10 \mathrm{mg} / \mathrm{ml})$. Bandas correspondendo a $600 \mathrm{pb}$ do BRMV-PR e de $594 \mathrm{pb}$ do CPSMVPR foram destacadas do gel e o DNA foi purificado com o Ultraclean $^{\mathrm{TM}} 15$ DNA purification kit (MOBIO Laboratories).

Os fragmentos amplificados foram clonados diretamente no plasmídeo pGEM $^{\circledR} \mathrm{T}$ (Promega), conforme instruções do fabricante. O seqüenciamento foi determinado por meio de um sequenciador automático Alf Express II (Pharmacia Biotech). Pelo menos dois clones independentes de cada isolado foram seqüenciados.

As seqüências de aminoácidos deduzidas dos fragmentos amplificados do CPSMV-PR e BRMV-PR foram obtidas utilizando-se o programa de tradução ExPASy (Molecular Biology Server, Swiss Institute of Bioinformatics) e foram comparadas com seqüências do RNA2 de outros virus do gênero Comovirus depositadas no GenBank: Red clover motlle virus (RCMV), número de acesso no GenBank M14913, Cowpea mosaic virus (CPMV), X00729, Cowpea severe mosaic virus (CPSMV), M83309, Bean pod mottle virus (BPMV), M62738, Andean potato mottle virus (APMV), L16239 e Squash mosaic virus (SqMV), M96148. Os alinhamentos múltiplos das seqüências foram conduzidos utilizando-se a versão 1.8 do programa Clustal W.

A comparação das seqüências de aminoácidos codificadas pelo fragmento do RNA2 do CPSMV-PR e BRMV$\mathrm{PR}$, com seqüências de comovirus depositadas no GenBank, demonstrou que, para esta região genômica, o CPSMV-PR apresentou $85 \%$ de homologia com o isolado americano do CPSMV, enquanto o isolado BRMV-PR apresentou 39\% de homologia com o CPSMV, $41 \%$ com o CPSMV-PR e $44 \%$ 
Análise molecular de segmento do RNA2 de Comovirus isolados...

com o BPMV (Tabela 1)

O CPSMV já foi considerado uma estirpe do CPMV, visto que os dois vírus apresentam fraca reação sorológica cruzada e gama de hospedeiras em comum. Posteriormente, o CPSMV foi reconhecido como um comovirus distinto (Fulton \& Scott, 1979). Comparações das seqüências completas dos RNA2 de comovirus sugerem que o CPSMV e CPMV não são as espécies mais próximas entre si. O CPSMV é mais próximo do BPMV e o CPMV mais similar ao RCMV do que a qualquer outro comovirus (Chen \& Bruening, 1992).

Os dados de seqüenciamento parcial do BRMV-PR e CPSMV-PR apresentados neste trabalho correspondem ao primeiro seqüenciamento de comovirus de leguminosas no Brasil e a primeira seqüência obtida para o BRMV (seqüências depositadas no GenBank database sob os números de acesso
AF263548 e AF263549).

O BRMV está presente no Brasil, Colômbia, Costa Rica, El Salvador, Guatemala e Panamá, e especialmente nas regiões produtoras de feijão do Estado do Paraná, onde vem assumindo importância crescente.

No Brasil, a ocorrência do CPSMV em infecções naturais de soja foi relatada pela primeira vez no Distrito Federal (Anjos \& Lin, 1980). No Paraná, é um evento novo e até o momento nenhuma fonte de resistência genética foi identificada no banco de germoplasma da Embrapa Soja (Bertacini et al., 1998).

Trabalhos de seqüenciamento completo do genoma do BRMV poderão contribuir para o melhor conhecimento da variabilidade genética deste vírus, fator importante para a obtenção de feijoeiro e de plantas de soja resistentes.

TABELA 1 - Percentagem de similaridade de aminoácidos baseada no alinhamento múltiplo das seqüências codificadas por segmento do RNA2 de diferentes vírus do gênero Comovirus

\begin{tabular}{lccccccc}
\hline \hline & CPSMV-PR & CPSMV & BPMV & RCMV & CPMV & SqMV & APMV \\
\hline BRMV-PR & $41^{*}$ & 39 & 44 & 39 & 31 & 31 & 28 \\
CPSMV-PR & & 85 & 51 & 46 & 42 & 38 & 32 \\
CPSMV & & & 45 & 37 & 37 & 43 & 26 \\
BPMV & & & 41 & 40 & 48 & 30 \\
RCMV & & & & & 44 & 44 & 30 \\
CPMV & & & & & & 42 & 27 \\
SqMV & & & & & & & 35 \\
\hline
\end{tabular}

* Valores obtidos pelo programa Clustal W (versão1.8). Foram comparadas entre si seqüências de aminoácidos codificadas pelo fragmento de 600 pb do RNA2 do BRMV-PR e de 594 pb do RNA2 do CPSMV-PR, com seqüencias do RNA2 de Comovirus depositadas no GenBank: CPSMV (Cowpea severe mosaic virus, M83309), BPMV (Bean pod mottle mosaic virus, M62738), RCMV (Red clover mottle virus, M14913), CPMV (Cowpea mosaic virus, X00729), SqMV (Squash mosaic virus, M96148), e APMV (Andean potato mottle virus, L16239).

\section{REFERÊNCIAS BIBLIOGRÁFICAS}

ANJOS, J.R.N. \& LIN, M.T. Queima do broto em soja causada por um membro do serotipo I do vírus do mosaico severo do caupi serogrupo Arkansas. Fitopatologia Brasileira 5:382-383. 1980.

BERTACINI, P.V., ALMEIDA, A.M.R., LIMA, J.A.A. \& CHAGAS, C.M. Biological and physicochemical properties of cowpea severe mosaic Comovirus isolated from soybean in the State of Paraná. Brazilian Archives of Biology and Technology 41:409-416. 1998.

BIANCHINI, A., KITAJIMA, E.W. \& LIN, M. T. Ocorrência do vírus do mosaico em desenho do feijoeiro no Estado do Paraná. Fitopatologia Brasileira 10:307. 1985 (Resumo).

BRIOSO, P.S.T., DUQUE, F.F., SAYÃO, F.A.D., LOURO, R.P., KITAJIMA, E.W. \& OLIVEIRA, D.E. Vírus do mosaico severo do caupi - Infecção natural em mungo verde, Vigna radiata. Fitopatologia Brasileira 19:420-429. 1994.

BRIOSO, P.S.T., SANTIAGO, L.J.M., ANJOS, J.R.N. \& OLIVEIRA, D.E. Identificação de espécies do gênero
Comovirus através de "polymerase chain reaction". Fitopatologia Brasileira 21:219-225. 1996.

CHEN, X. \& BRUENING, G. Nucleotide sequence and genetic map of cowpea severe mosaic virus RNA2 and comparisons with RNA2 of other comoviruses. Virology 187:682-692. 1992.

CUPERTINO, F.P., COSTA, C.L., LIN, M.T.\& KITAJIMA, E.W. Infecções simples e mistas dos vírus do mosaico do sul e do mosaico em desenho em feijão vagem no Brasil Central. Fitopatologia Brasileira 7:269-274. 1982.

CUPERTINO, F.P., COSTA, C.L. \& KITAJIMA, E.W. Infecção natural da soja pelo vírus do mosaico em desenho do feijoeiro no Distrito Federal. Fitopatologia Brasileira 16:246-250. 1991.

FULTON, J.P. \& SCOTT, H.A. A serogrouping concept for legume comoviruses. Phytopathology 69:305-306. 1979.

MARTINS, T.R., ALMEIDA, A.M.R., ALMEIDA, L.A., NEPOMUCENO, A., CHAGAS, C.M. \& TOLEDO, J.F.F. Sinergismo observado em plantas de soja infectadas pelo vírus do mosaico comum da soja e do mosaico-em-desenho do feijoeiro. Fitopatologia Brasileira 19:430-436. 1994. 